\title{
Stability Indicating Square-Wave Stripping Voltammetric Method for Determination of Gatifloxacin in Pharmaceutical Formulation and Human Blood
}

\author{
Hanaa Salah El-Desoky \\ Analytical \& Electrochemistry Research Unit, Department of Chemistry, Faculty of Science, \\ Tanta University, 31527-Tanta, Egypt
}

\begin{abstract}
Um método de voltametria de re-dissolução catódica adsortiva de onda quadrada, indicativa de estabilidade, completamente validado, sensível e preciso foi desenvolvido para determinação de gatifloxacina na forma bruta, em formulações farmacêuticas e em amostras de plasma e soro humano. Os limites de detecção encontrados de gatifloxacina na forma bruta e no soro humano foram $1,5 \times 10^{-9}$ e $2,2 \times 10^{-9} \mathrm{~mol} \mathrm{~L}^{-1}$, respectivamente. $\mathrm{O}$ método descrito foi aplicado com sucesso na determinação de gatifloxacina em formulações farmacêuticas e em amostras biológicas humanas sem extração prévia às análises. Interferências de excipientes comuns, de alguns íons de metais comuns, de espécies orgânicas, de fármacos co-administrados e de produtos de degradação induzida por ácido não foram significativos, durante a análise de gatifloxacina nas diversas amostras analisadas. Além disso, parâmetros farmacocinéticos de gatifloxacina em plasma de voluntários saudáveis, após a administração de uma dose oral (400 mg de gatifloxacina) foram também estimados por meio do método voltamétrico de re-dissolução descrito.
\end{abstract}

A fully validated, sensitive and precise stability-indicating square-wave adsorptive cathodic stripping voltammetric method has been developed for determination of gatifloxacin in the bulk form, pharmaceutical formulation, and in spiked human serum and real plasma samples. The achieved detection limits of gatifloxacin in the bulk form and human serum were $1.5 \times 10^{-9}$ and $2.2 \times 10^{-9} \mathrm{~mol} \mathrm{~L}^{-1}$, respectively. The described method was applied successfully for determination of gatifloxacin in formulation and human biological samples without extraction prior to the analysis. No significant interferences from common excipients, some common metal ions, organic species, co-administrated drugs and from the acid-induced degradation products were obtained during analysis of gatifloxacin in the various analyzed samples. Besides, pharmacokinetic parameters of gatifloxacin in plasma of healthy volunteers following the administration of an oral single dose (400 mg gatifloxacin) were also estimated by means of the described stripping voltammetric method.

Keywords: gatifloxacin, tequin tablets, human blood, stripping voltammetry, pharmacokinetic parameters

\section{Introduction}

Gatifloxacin (1-cyclopropyl-6-fluoro-1, 4-dihydro-8methoxy-7-[3-methyl-1-piperazinyl]-4-oxo-3-quinoline carboxylic acid), (Scheme 1), is a synthetic broad-spectrum antimicrobial fluoroquinolone. It is active against both gram-negative and gram-positive bacteria and used in the treatment of a wide range of infections. ${ }^{1,2}$ Its absolute bioavailability is $96 \%$, with mean peak plasma concentration of 3.1 to $3.6 \mu \mathrm{g} \mathrm{mL}^{-1}$ usually occurring within 1.0 to $2.0 \mathrm{~h}$ after administration of an oral single dosing of a $400 \mathrm{mg}$ gatifloxacin..$^{2-4}$ It undergoes limited biotransformation in humans with less than $1 \%$ of the dose excreted in the

*e-mail: hseldesoky@ hotmail.com urine as ethylenediamine and methylethylenediamine metabolites. ${ }^{2}$<smiles>COc1c(N2CCNC(C)C2)c(F)cc2c(=O)c(C(=O)O)cn(C3CC3)c12</smiles>

Scheme 1. Chemical structure of gatifloxacin.

Various instrumental analytical methods have been described for assay of gatifloxacin in bulk form, pharmaceutical formulation and biological fluids. These include high-performance liquid chromatography, ${ }^{5-13}$ high-performance thin-layer chromatography, ${ }^{14-16}$ 
liquid chromatography, ${ }^{17,18}$ spectrofluorimetry, ${ }^{19-22}$ spectrophotometry, ${ }^{23-28}$ capillary electrophoresis, ${ }^{29-32}$ chemiluminescence, ${ }^{33,34}$ voltammetry at a carbon paste electrode, ${ }^{35-38}$ and atomic absorption spectrometry. ${ }^{39-41}$ Most of the reported methods for assay of gatifloxacin necessitate samples pretreatment and time-consuming extraction steps prior to the analysis and required expensive equipment and considerable skills are necessary to operate them successfully. To date no square-wave adsorptive cathodic stripping voltammetric method is reported in the literature for determination of gatifloxacin.

So, the aim of the present work was to develop a fully validated stability-indicating square-wave adsorptive cathodic stripping voltammetic method for determination of gatifloxacin in pharmaceutical formulation and human blood without extraction prior to the analysis and without significant interferences from inorganic and organic species.

\section{Experimental}

\section{Instruments}

Computer-controlled Electrochemical Analyzers Models 263A and 394-PAR (Princeton Applied Research, Oak Ridge, TN, USA) with the software package 270/250PAR were used for the voltammetric measurements. An electrode assembly (303A-PAR) incorporated with a micro-electrochemical cell and a three-electrode system comprising of a hanging mercury drop electrode (HMDE) as a working electrode (surface area $=0.026 \mathrm{~cm}^{2}$ ), an $\mathrm{Ag} / \mathrm{AgCl} / \mathrm{KCl}_{\mathrm{s}}$ reference electrode and a platinum wire auxiliary electrode, was used. A magnetic stirrer (305PAR) and a stirring bar were used to provide the convective transport during the accumulation step.

\section{Materials and solutions}

(i) A stock standard solution of $1.0 \times 10^{-3} \mathrm{~mol} \mathrm{~L}^{-1}$ bulk gatifloxacin (Bristol-Myers Squibb Company, New YorkCairo) was prepared in ethanol (Merck), and then stored at $4{ }^{\circ} \mathrm{C}$. Working solutions of gatifloxacin $\left(1.0 \times 10^{-6}\right.$ to $1.0 \times 10^{-4} \mathrm{~mol} \mathrm{~L}^{-1}$ ) were prepared daily by appropriate dilution with ethanol just before use. (ii) Ten tequin ${ }^{\circledR}$ tablets (Bristol-Myers Squibb Company, New York-Cairo) labeled to contain $400 \mathrm{mg}$ gatifloxacin per tablet were quantitatively weighed and the average mass per tablet was determined. The tablets were then grounded in a mortar to a homogeneous fine powder. A quantity of this powder equivalent to the weight of one tablet was accurately transferred into a $100.0 \mathrm{~mL}$ volume calibrated flask containing $70 \mathrm{~mL}$ ethanol (Merck). The content of the flask was sonicated for about $10 \mathrm{~min}$ and then filled up with ethanol. The solution was then filtered through a $0.45 \mu \mathrm{m}$ Milli-pore filter (Gelman, Germany). The desired concentrations of the gatifloxacin were obtained by accurate dilution with ethanol. (iii) Serum sample of a healthy volunteer was stored frozen until assay. A $1.0 \mathrm{~mL}$ volume of the human serum was transferred to each of 10 centrifugation tubes (3.0 $\mathrm{mL}$ volume polypropylene micro-centrifuge tubes), containing a certain concentration of gatifloxacin $\left(1.0 \times 10^{-6}\right.$ to $\left.1.0 \times 10^{-4} \mathrm{~mol} \mathrm{~L}^{-1}\right)$, and, then, mixed well with $1.0 \mathrm{~mL}$ of ethanol to denature and precipitate proteins. The solutions were centrifuged (using an Eppendorf centrifuge 5417C, Hamburg, Germany) for $3 \mathrm{~min}$ at $14000 \mathrm{rpm}$ to separate out the precipitated proteins. The clear supernatant layers of the solutions were filtered through $0.45 \mu \mathrm{m}$ Milli-pore filters to produce protein-free human serum samples spiked with various concentrations of gatifloxacin $\left(1.0 \times 10^{-6}\right.$ to $1.0 \times 10^{-4} \mathrm{~mol} \mathrm{~L}^{-1}$ ). (iv) A series of Britton-Robinson (B-R) universal buffers of $\mathrm{pH} 2.0$ to 11.5 as supporting electrolytes was prepared. A pH-meter (Crison, Barcelona, Spain) was used for the $\mathrm{pH}$ measurements. Deionized water was supplied from a Purite-Still Plus de-ionizer connected to an AquaMatic double-distillation water system (Hamilton Laboratory Glass LTD, Kent, UK). All the chemicals used were of analytical-grade reagents.

\section{Induced degradation of gatifloxacin}

$10.0 \mathrm{~mL}$ of $\mathrm{HCl}$ solution $\left(5.0 \mathrm{~mol} \mathrm{~L}^{-1}\right)$ or $10.0 \mathrm{~mL}$ of $\mathrm{NaOH}$ solution $\left(5.0 \mathrm{~mol} \mathrm{~L}^{-1}\right)$ were mixed with $10.0 \mathrm{~mL}$ of ethanolic gatifloxacin solution $\left(2.5 \times 10^{-3} \mathrm{~mol} \mathrm{~L}^{-1}\right)$, and then subjected to forced degradation by refluxing in the dark in two-necked round-bottomed flask ( $50 \mathrm{~mL}$ volume) for $8 \mathrm{~h}$. At adequate time intervals, certain volume of each of the refluxed solutions was withdrawn with micropipette to a glass tube and immediately cooled in ice path then diluted with ethanol to give a final concentration of $1.0 \times 10^{-4} \mathrm{~mol} \mathrm{~L}^{-1}$ gatifloxacin. A known volume $(50.0 \mu \mathrm{L})$ of each of these solutions was introduced into a $10.0 \mathrm{~mL}$ volume calibrated flask then filled up with a B-R universal buffer of $\mathrm{pH} 7$ to give a final concentration of $5.0 \times 10^{-7} \mathrm{~mol} \mathrm{~L}^{-1}$ gatifloxacin (Final $\mathrm{pH}$ was adjusted to $\mathrm{pH} 7$ with $0.01 \mathrm{~mol} \mathrm{~L}^{-1} \mathrm{NaOH}$ or $0.01 \mathrm{~mol} \mathrm{~L}^{-1} \mathrm{HCl}$ ). Recoveries based on three replicate measurements of gatifloxacin in each treated sample were estimated by means of the described SW-AdCS voltammetric method.

\section{Pharmacokinetic studies}

A pharmacokinetic study was performed on plasma samples of two healthy volunteers. The two volunteers gave 
their written informed consent prior to anticipating in the study at Ramadan Specialized Hospital (Tanta City, Egypt). They were caffeine and alcohol free and avoided all medication for at least $24 \mathrm{~h}$ before and during study. Each volunteer received an oral single dose of tequin ${ }^{\circledR}$ tablet (400 $\mathrm{mg}$ gatifloxacin). A venous blood sample $(1.0 \mathrm{~mL}$ each) was obtained immediately before drug administration to serve as a blank (baseline) and then the sampling was continued at $0.5,1,1.5,2,3,4,6,8,12$ and $24 \mathrm{~h}$ after the administration of the oral dose. The blood samples were centrifuged immediately at $2000 \mathrm{rpm}$ for $10 \mathrm{~min}$ and the plasma fractions were rapidly separated and stored in coded polypropylene tubes at $-20^{\circ} \mathrm{C}$ until assayed. Following precipitation of proteins by ethanol and then separation by centrifugation, the plasma samples were analyzed using the described voltammetric method.

\section{Results and Discussion}

\section{Cyclic voltammetric studies}

Cyclic voltammograms of $1.0 \times 10^{-4} \mathrm{~mol} \mathrm{~L}^{-1}$ gatifloxacin recorded at the HMDE in the Britton-Robinson (B-R) universal buffer of $\mathrm{pH}$ values 3.5 to 8 exhibited a single 2-electron irreversible cathodic peak. Its peak current decreased gradually upon the increase of $\mathrm{pH}$ of the medium until its disappearence at $\mathrm{pH}>10$, while a second ill-defined cathodic peak appeared at more negative potentials, in solutions of $\mathrm{pH}$ values $\geq 8.5$, Figure 1 . This behavior may be attributed to the reduction of the $\mathrm{C}=\mathrm{O}$ double bond of reactant species in the acidic and basic solutions. No peaks were observed in the anodic scan; pointing to the irreversible nature of the reduction process. The $2^{\text {nd }}$ cathodic peak ( $\mathrm{pH} \geq 8.5$ ) was ill-defined due to its overlapping with

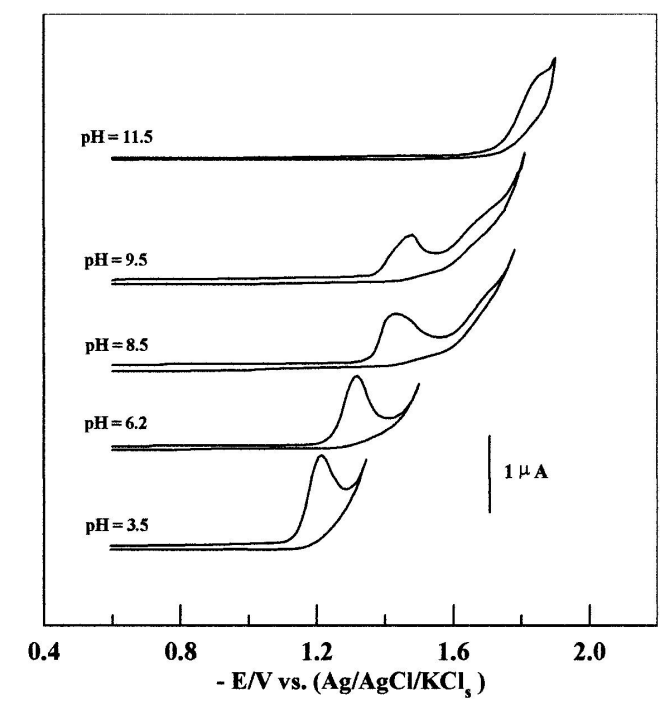

Figure 1. Cyclic voltammograms of $1.0 \times 10^{-4} \mathrm{~mol} \mathrm{~L}^{-1}$ gatifloxacin solution in B-R universal buffer of different $\mathrm{pH}$ at a scan rate of $100 \mathrm{mVs}^{-1}$. that of the supporting electrolyte; therefore it can not be used for any subsequent studies.

As shown in Figure 1, the $\mathrm{i}_{\mathrm{p}}$ versus $\mathrm{pH}$ plot of the $1^{\text {st }}$ peak $(\mathrm{pH}<9)$ is a Z-shaped curve (recalls a dissociation curve) indicating the presence of an acid-base equilibrium in the reduction of gatifloxacin. ${ }^{22}$ The $\mathrm{pH}$ value corresponding to the half-height of the $\mathrm{i}_{\mathrm{p}}$ versus $\mathrm{pH}$ plot or to the peak of $\delta \mathrm{i}_{\mathrm{p}} / \delta \mathrm{pH}$ versus $\mathrm{pH}$ plot of the 1st peak (Figure 2) was found to be 6.2. This value $\left(\mathrm{pH}=\mathrm{pK}_{\mathrm{a}}=6.2\right)$ agrees well with those reported in the literature for $\mathrm{pK}_{\mathrm{a} 1}$ of gatifloxacin and different fluoroquinolones (6.19 and 6.03) $)^{22,31}$ which is due to dissociation of their carboxylic group. On the other hand, the peak potential $\mathrm{E}_{\mathrm{p}}$ of the $1^{\text {st }}$ peak shifted to more negative values with the increase of $\mathrm{pH}$, denoting that protons are involved in the electrode reaction process and the proton-transfer reaction precedes the electron transfer process. ${ }^{42}$ As shown in Figure 3, $\mathrm{E}_{\mathrm{p}}$ versus $\mathrm{pH}$ plot of the $1^{\text {st }}$ peak $(\mathrm{pH}<9)$ exhibited two segments intersected at $\mathrm{pH} 6.2$ which can be considered again to equal the first equilibrium constant of gatifloxacin. ${ }^{22,31}$

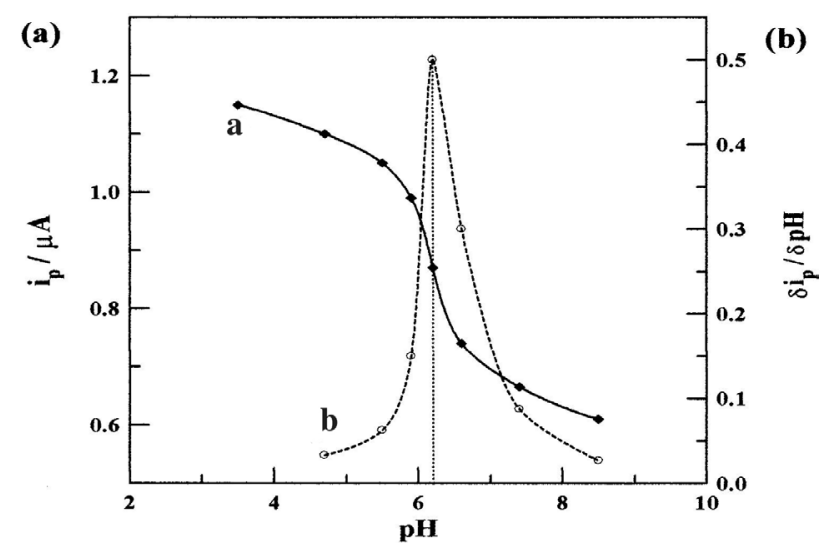

Figure 2. Plots of $\mathrm{i}_{\mathrm{p}}$ versus $\mathrm{pH}$ (curve a) and $\delta \mathrm{i}_{\mathrm{p}} / \delta \mathrm{pH}$ versus $\mathrm{pH}$ (curve b) of $1.0 \times 10^{-4} \mathrm{~mol} \mathrm{~L}^{-1}$ gatifloxacin in B-R universal buffer of various $\mathrm{pH}$ values at a scan rate of $100 \mathrm{mVs}^{-1}$.

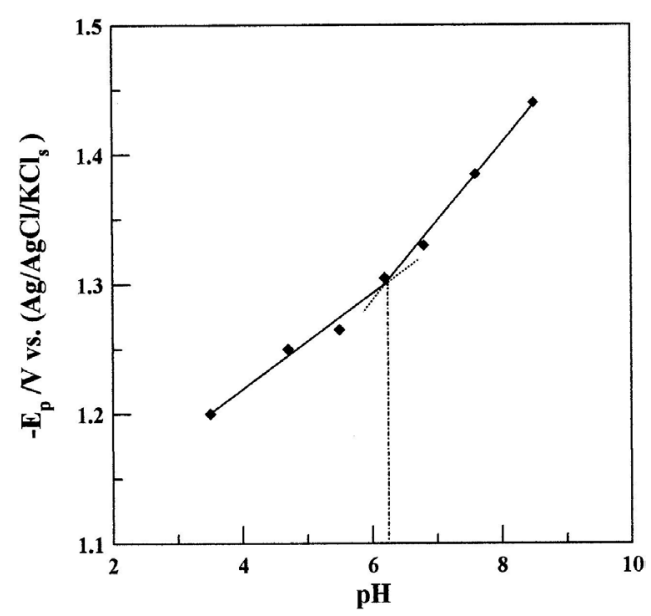

Figure 3. $\mathrm{E}_{\mathrm{p}}$ versus $\mathrm{pH}$ of the medium for $1.0 \times 10^{-4} \mathrm{~mol} \mathrm{~L}^{-1}$ gatifloxacin solution at a scan rate of $100 \mathrm{mVs}^{-1}$. 
Effect of the scan rate $v\left(20\right.$ to $500 \mathrm{mV} \mathrm{s}^{-1}$ ) on either the peak potential $\left(\mathrm{E}_{\mathrm{p}}\right)$ and peak current $\left(\mathrm{i}_{\mathrm{p}}\right)$ of the $1^{\text {st }}$ peak was examined at different $\mathrm{pH}$ values $(\mathrm{pH}<9)$. The peak potentials $\left(\mathrm{E}_{\mathrm{p}}\right)$ were linearly shifted to more negative values with the increase of scan rate $(v)$ confirming the irreversible nature of the reduction processes of gatifloxacin at HMDE. ${ }^{43}$ Linear $\mathrm{E}_{\mathrm{p}}$ versus $\log v$ plots $^{44}$ of slope values of 52 to $66 \mathrm{mV}$ were obtained; from which values of $\alpha \mathrm{n}_{\mathrm{a}}$ (product of transfer coefficient $\alpha$ and number of electrons $n_{\mathrm{a}}$ transferred in the rate-determining step) were estimated and found to equal 1.14 to 0.89 . Since, the number of electrons $n_{a}$, transferred in the rate-determining step of the electroreduction of the $\mathrm{C}=\mathrm{O}$ double bond of the analyte equals $2\left(n_{a}=2\right)^{42}$ the transfer coefficient $\alpha$ should be 0.57 to 0.45 .

Linear Randles-Sevcik plots ( $\mathrm{i}_{\mathrm{p}}$ versus $v$ ) were obtained for the $1^{\text {st }}$ peak at different $\mathrm{pH}$ values $<9$ with slope values 5.9 to $6.5 \mu \mathrm{A} \mathrm{V}^{-1} \mathrm{~s}(\mathrm{r}=0.998 \pm 0.002$ and $\mathrm{n}=5)$ indicating that the reduction process of gatifloxacin at the HMDE is controlled by adsorption. ${ }^{45,46}$ This finding was confirmed by the linear plots of $\log i_{\mathrm{p}}$ versus $\log \mathrm{v}$, obtained for the $1^{\text {st }}$ peaks $(\mathrm{pH}<9)$ with slope values of 0.78 to $0.92 \mu \mathrm{A} \mathrm{mV}^{-1} \mathrm{~s}$; $(\mathrm{r}=0.999 \pm 0.001, \mathrm{n}=5)$ which are close to the theoretical values of 1.0 expected for the electrode reaction of surface species. ${ }^{47}$

The interfacial adsorptive character of gatifloxacin onto the HMDE was identified by means of cyclic voltammetry in the B-R universal buffer. Figure 3 shows the cyclic voltammograms of $5.0 \times 10^{-7} \mathrm{~mol} \mathrm{~L}^{-1}$ bulk gatifloxacin recorded in a B-R universal buffer of $\mathrm{pH} 7$ following preconcentration onto the HMDE by adsorptive accumulation at open circuit conditions (curve a), and then at $-0.7 \mathrm{~V}$ for $60 \mathrm{~s}\left(1^{\text {st }}\right.$ cycle $\mathrm{b}$ and $2^{\text {nd }}$ cycle $\left.\mathrm{c}\right)$. A better enhanced peak current magnitude was achieved following preconcentration of gatifloxacin by adsorptive accumulation onto the electrode surface (Figure 4, $1^{\text {st }}$ cycle b) whereas the $2^{\text {nd }}$ cycle exhibited a lower peak current magnitude (Figure 4, $2^{\text {nd }}$ cycle c). This behavior indicated the interfacial adsorptive character of gatifloxacin onto the mercury electrode surface.

The electrode surface coverage $\Gamma_{0}$ (amount of reactant adsorbed onto the mercury electrode surface, $\mathrm{mol} \mathrm{cm}$ ) was calculated using the relation: $\Gamma_{0}=\mathrm{Q} / \mathrm{nFA}$, where $\mathrm{Q}$ is the amount of charge consumed by the surface process as calculated by the integration of the area under the peak of the cyclic voltammogram corrected for residual current, $\mathrm{n}$ is the total number of electrons consumed in the reduction process $(\mathrm{n}=2)$ and $\mathrm{A}$ is the mercury electrode surface area $\left(0.026 \mathrm{~cm}^{2}\right)$. On dividing the number of coulombs transferred $1.23 \mu \mathrm{C}$ by the conversion factor nFA $\left(5017.30 \times 10^{6} \mu \mathrm{C}\right)$, a surface coverage of $2.45 \times 10^{-10} \mathrm{~mol} \mathrm{~cm}^{-2}$ was estimated. Thus, each adsorbed gatifloxacin molecule occupies an area of $0.68 \mathrm{~nm}^{2}$.

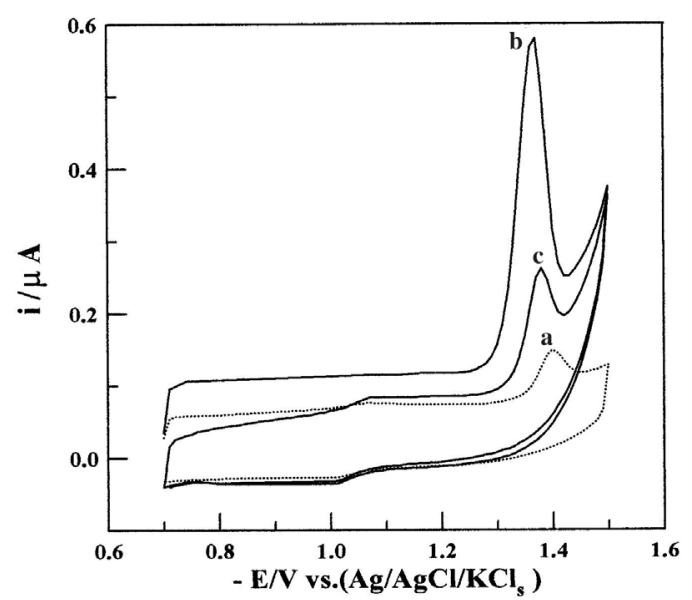

Figure 4. Cyclic voltammograms of $5.0 \times 10^{-7} \mathrm{~mol} \mathrm{~L}^{-1}$ bulk gatifloxacin in a B-R universal buffer of $\mathrm{pH} 7.0$ at a scan rate of $100 \mathrm{mVs}^{-1}$ recorded following preconcentration by adsorptive accumulation onto the HMDE at open circuit conditions (a) and then at $\mathrm{E}_{\text {acc. }}=-0.7 \mathrm{~V}$ for $60 \mathrm{~s}\left(1^{\text {st }}\right.$ cycle $\mathrm{b}$ and $2^{\text {nd }}$ cycle $\mathrm{c}$ ).

\section{Stripping voltammetric studies}

Square-wave adsorptive cathodic stripping voltammograms of $5.0 \times 10^{-7} \mathrm{~mol} \mathrm{~L}^{-1}$ gatifloxacin recorded following its preconcentration by adsorptive accumulation onto the HMDE at $-0.5 \mathrm{~V}$ for $30 \mathrm{~s}$ exhibited a single irreversible cathodic peak in the B-R universal buffer of $\mathrm{pH}$ values $<8.5$; a better developed and sharper peak was obtained at $\mathrm{pH}$ 7. Therefore a B-R universal buffer of $\mathrm{pH} 7$ was used as a supporting electrolyte in the rest of the present analytical study. Effect of square-wave pulse parameters (frequency $\mathrm{f}$ (10 to $100 \mathrm{~Hz}$ ), scan increment $\Delta \mathrm{E}_{\mathrm{s}}$ (2 to $10 \mathrm{mV}$ ) and pulse-amplitude a (10 to $50 \mathrm{mV})$ ) on the peak current magnitude of $5.0 \times 10^{-7} \mathrm{~mol} \mathrm{~L}^{-1}$ gatifloxacin in a B-R universal buffer of $\mathrm{pH} 7$ following its preconcentration by adsorptive accumulation onto the HMDE at $\mathrm{E}_{\text {acc. }}=-0.5 \mathrm{~V}$ for $30 \mathrm{~s}$ was studied. A better developed peak current magnitude was achieved at $\mathrm{f}=80 \mathrm{~Hz}, \Delta \mathrm{E}_{\mathrm{s}}=10 \mathrm{mV}$ and $\mathrm{a}=25 \mathrm{mV}$.

On the other side, effect of accumulation potential $\left(\mathrm{E}_{\text {acc. }}\right)$ on the SW-AdCS voltammetric peak current magnitude of $5.0 \times 10^{-7} \mathrm{~mol} \mathrm{~L}^{-1}$ gatifloxacin in a B-R universal buffer of $\mathrm{pH} 7$ was examined over the range 0.0 to $-1.1 \mathrm{~V}(v s$. Ag/ $\mathrm{AgCl} / \mathrm{KCl}_{\mathrm{s}}$ ) following its preconcentration by adsorptive accumulation onto the HMDE for $30 \mathrm{~s}$. A better enhanced peak current magnitude was achieved over the potential range -0.5 to $-0.9 \mathrm{~V}$; hence, an accumulation potential of $-0.7 \mathrm{~V}$ was chosen throughout the present study. Effect of preconcentration time $\left(t_{\text {acc }}\right)$ at $-0.7 \mathrm{~V}$ on the peak current magnitude for various concentrations of bulk gatifloxacin $\left(5.0 \times 10^{-7}, 1.0 \times 10^{-7}\right.$ and $\left.1.0 \times 10^{-8} \mathrm{~mol} \mathrm{~L}^{-1}\right)$ in a B-R universal buffer of $\mathrm{pH} 7$ was also evaluated. As shown in Figure 5, for $5.0 \times 10^{-7}, 1.0 \times 10^{-7}$ and $1.0 \times 10^{-8} \mathrm{~mol} \mathrm{~L}^{-1}$ gatifloxacin the 
response was linear up to 40, 100 and $120 \mathrm{~s}$, respectively. This means that the lower the concentration of the analyte, the longer of the accumulation duration is. Thus, the accumulation duration of choice will be dictated by the sensitivity needed. So, accumulation times of 100, 60 and $30 \mathrm{~s}$ were applied in the present work (Table 1).

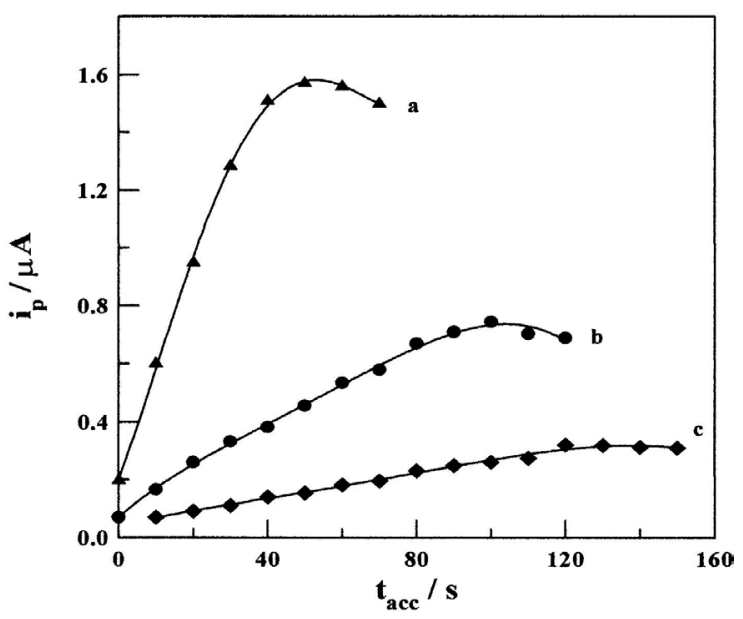

Figure 5. Effect of accumulation time $\left(\mathrm{t}_{\text {acc }}\right)$ on the SW-AdCS voltammetric peak current magnitude for: (a) $5.0 \times 10^{-7} \mathrm{~mol} \mathrm{~L}^{-1}$, (b) $1.0 \times 10^{-7} \mathrm{~mol} \mathrm{~L}^{-1}$ and (c) $1.0 \times 10^{-8} \mathrm{~mol} \mathrm{~L}^{-1}$ gatifloxacin in a B-R universal buffer of $\mathrm{pH} 7$; $\mathrm{E}_{\text {acc. }}=-0.7 \mathrm{~V}, \mathrm{f}=80 \mathrm{~Hz}, \Delta \mathrm{E}_{\mathrm{s}}=10 \mathrm{mV}$ and $\mathrm{a}=25 \mathrm{mV}$.

To allow formation of a uniform distribution of the accumulated analyte onto the mercury surface, rest time was employed between the preconcentration and stripping steps. The influence of the rest time of 5.0 and $10.0 \mathrm{~s}$ on reproducibility of the peak current was studied and a rest time period of $5.0 \mathrm{~s}$ was chosen for the present analytical study, since at which sharp and better enhanced peak current was obtained.
Accordingly, the optimum operational conditions of the described stripping voltammetric method for assay of gatifloxacin were: $\mathrm{E}_{\text {acc }}=-0.7 \mathrm{~V}, \mathrm{t}_{\mathrm{acc}} \leq 120 \mathrm{~s}, \mathrm{f}=80 \mathrm{~Hz}$, $\Delta \mathrm{E}_{\mathrm{s}}=10 \mathrm{mV}, \mathrm{a}=25 \mathrm{mV}$ and a B-R universal buffer of $\mathrm{pH} 7$ as a supporting electrolyte.

\section{Validation of the method}

Validation of the described stripping voltammetric method for assay of bulk gatifloxacin was examined via evaluation of the linear dynamic range, limit of detection (LOD), limit of quantitation (LOQ), repeatability, reproducibility, precision, robustness and intermediate precision. Linear calibration plots over various concentration ranges of bulk gatifloxacin, at various accumulation durations were obtained and the characteristics of these plots are reported in Table 1. Values of LOD and LOQ were estimated using the expression: $\mathrm{k}$ S.D./ $\mathrm{b},{ }^{48}$ where $\mathrm{k}=3$ for LOD and 10 for LOQ, S.D. is the standard deviation of the blank (or the intercept of the calibration plot) and $b$ is the slope of the calibration plot. The results reported in Table (1), indicated the reliability of the described SW-AdCS voltammetric method for the trace assay of bulk gatifloxacin.

The repeatability, reproducibility, precision and accuracy $^{49}$ of analysis using the described stripping voltammetric method were identified by performing four replicate measurements for each of $5.0 \times 10^{-8}$ and $1.0 \times 10^{-7} \mathrm{~mol} \mathrm{~L}^{-1}$ bulk gatifloxacin $\left(\mathrm{t}_{\text {acc. }}=100 \mathrm{~s}\right.$ and $\mathrm{E}_{\text {acc. }}=-0.7 \mathrm{~V}$ ) over one day (Intra- day assay) and for three successive days (Inter- day assay). Satisfactory mean percentage recoveries (\%R) for intra- and interday precisions and accuracy were achieved (Table 2).

Table 1. Characteristics of the calibration curves of SW-AdCS voltammetric determination of bulk gatifloxacin in a B-R universal buffer of pH 7; $\mathrm{E}_{\text {acc. }}=-0.7 \mathrm{~V}, \mathrm{f}=80 \mathrm{~Hz}, \Delta \mathrm{E}_{\mathrm{s}}=10 \mathrm{mV}$ and $\mathrm{a}=25 \mathrm{mV}$, at $25^{\circ} \mathrm{C}$

\begin{tabular}{|c|c|c|c|c|c|}
\hline $\mathrm{t}_{\mathrm{acc}} / \mathrm{s}$ & $\begin{array}{l}\text { Linearity range / } \\
\left(\mathrm{mol} \mathrm{L}^{-1}\right)\end{array}$ & $\begin{array}{c}\text { Regression equation } \\
\mathrm{i}_{\mathrm{p}}(\mu \mathrm{A})=\mathrm{bC}\left(\mu \mathrm{mol} \mathrm{L} \mathrm{L}^{-1}\right)+\mathrm{a}\end{array}$ & (r) & $\begin{array}{c}\mathrm{LOD} / \\
\left(\mathrm{mol} \mathrm{L}^{-1}\right)\end{array}$ & $\begin{array}{c}\mathrm{LOQ} / \\
\left(\mathrm{mol} \mathrm{L}^{-1}\right)\end{array}$ \\
\hline 30 & $3.0 \times 10^{-8}-7.0 \times 10^{-7}$ & $\mathrm{i}_{\mathrm{p}}=2.260 \mathrm{C}+0.151$ & 0.996 & $9.0 \times 10^{-9}$ & $3.0 \times 10^{-8}$ \\
\hline 60 & $1.0 \times 10^{-8}-4.0 \times 10^{-7}$ & $i_{p}^{p}=3.506 C+0.155$ & 0.993 & $3.0 \times 10^{-9}$ & $1.0 \times 10^{-8}$ \\
\hline 100 & $5.0 \times 10^{-9}-3.0 \times 10^{-7}$ & $i_{p}^{p}=4.256 C+0.175$ & 0.999 & $1.5 \times 10^{-9}$ & $5.0 \times 10^{-9}$ \\
\hline
\end{tabular}

Table 2. Analytical precision and accuracy of bulk gatifloxacin determination by the described SW-AdCS voltammetric method $(n=4)$ in a B-R universal buffer of $\mathrm{pH} 7 ; \mathrm{t}_{\text {acc }}=100 \mathrm{~s}$

\begin{tabular}{|c|c|c|c|c|c|}
\hline $\mathrm{C}_{\text {Taken }} /\left(\mathrm{mol} \mathrm{L}^{-1}\right)$ & $\mathrm{C}_{\mathrm{Found}} /\left(\mathrm{mol} \mathrm{L}^{-1}\right)$ & $\% \mathrm{R}$ & S.D. & Accuracy (RE\%) & Precision (RSD\%) \\
\hline \multicolumn{6}{|l|}{ Intra-day } \\
\hline $5.0 \times 10^{-8}$ & $5.01 \times 10^{-8}$ & 100.20 & 0.017 & 0.20 & 0.34 \\
\hline $1.0 \times 10^{-7}$ & $9.97 \times 10^{-6}$ & 99.70 & 0.005 & -0.30 & 0.50 \\
\hline \multicolumn{6}{|l|}{ Inter-day } \\
\hline $5.0 \times 10^{-8}$ & $5.02 \times 10^{-8}$ & 100.40 & 0.014 & 0.40 & 0.28 \\
\hline $1.0 \times 10^{-7}$ & $9.82 \times 10^{-6}$ & 98.20 & 0.006 & -1.80 & 0.61 \\
\hline
\end{tabular}


No significant differences were observed between the amounts taken and found of gatifloxacin which indicated the reproducibility, precision and accuracy of the described voltammetric method for assay of gatifloxacin.

For the study of the interference from excipients usually present in gatifloxacin formulation, $1.0 \times 10^{-7} \mathrm{~mol} \mathrm{~L}^{-1}$ standard bulk gatifloxacin solution and then a standard solution of tequin ${ }^{\circledR}$ tablets containing $1.0 \times 10^{-7} \mathrm{~mol} \mathrm{~L}^{-1}$ gatifloxacin were analyzed following preconcentration by adsorptive accumulation onto the HMDE at $-0.7 \mathrm{~V}$ for $100 \mathrm{~s}$ in both cases. No significant differences in percentage recoveries or the relative standard deviations achieved in the absence $(99.88 \pm 0.94)$ and in the presence $(99.59 \pm$ 1.06) of excipients. Thus, no significant interference from the excipients to the assay of gatifloxacin was observed by the described electroanalytical method.

Since the robustness ${ }^{49}$ of results of an analytical method is the ability to remain unaffected with some limited changes of the operational conditions, analysis of $1.0 \times 10^{-7} \mathrm{~mol} \mathrm{~L}^{-1}$ bulk gatifloxacin by means of the described method was carried out under various conditions ( $\mathrm{pH} 7$ to 7.5 , accumulation potential $=-0.5$ to $-0.7 \mathrm{~V}$, and accumulation duration $=90$ to $100 \mathrm{~s}$ ). The obtained mean percentage recoveries $(99.88 \pm 0.94$ to $98.45 \pm 0.88)$ were insignificantly affected within the studied conditions, and consequently the described SW-AdCS voltammetric method was reliable for assay of bulk gatifloxacin and it could be considered robust. ${ }^{49}$

The inter-laboratory precision of the measurements using the described method was examined by assay of $1.0 \times 10^{-7} \mathrm{~mol} \mathrm{~L}^{-1}$ gatifloxacin using two PAR- PotentiostatsModels 263A, Lab. (1) and 394, Lab. (2) under the same operational conditions at different elapsed times by two different analysts. The mean percentage recoveries obtained due to Lab. $1(99.88 \pm 0.94)$ to Lab. $2(98.50 \pm 0.88)$ and even day to day $(99.10 \pm 0.25$ to $98.42 \pm 0.65)$ were found reproducible, since there is no significant difference between the recoveries or relative standard deviations.

\section{Acid- induced degradation studies}

Stability testing has emerged in the field of pharmaceuticals as being very important to maintain the efficacy of a drug, as it provides measurements of the storage capacity of a drug, as well as demonstrates the safety of the drug products. Also, stability testing is a requirement for the regulatory approval during product marketing, and is a vital component of the overall quality control program. The International Conference on Harmonization (ICH) guideline entitled ${ }^{50}$ 'Stability testing of new drug substances and products' requires that stress testing be carried out to elucidate the inherent stability characteristics of the active substance. Susceptibility hydrolysis of analyte under acidic or basic conditions is one of the most required tests. An ideal stability-indicating method is one that quantifies the standard drug alone and also resolves its degradation products. Therefore, it was thought necessary to develop a simple and accurate stability-indicating method for the determination of gatifloxacin in the presence of its degradation products.

SW-AdCS voltammogram of $5.0 \times 10^{-7} \mathrm{~mol} \mathrm{~L}^{-1}$ of the gatifloxacin solution treated for different time intervals with $2.5 \mathrm{~mol} \mathrm{~L}^{-1} \mathrm{HCl}$ for $8 \mathrm{~h}$ (as described in the experimental section), recorded at the HMDE in a B-R universal buffer of $\mathrm{pH} 7$ showed a new less intense cathodic peak at less negative potential $\left(\mathrm{E}_{\mathrm{p}}=-1.20 \mathrm{~V}\right)$ in addition to the mean cathodic peak of gatifloxacin $\left(\mathrm{E}_{\mathrm{p}}=-1.45 \mathrm{~V}\right)$, Figure 6 . The peak current magnitude of the mean cathodic peak $\left(2^{\text {nd }}\right.$ peak) showed a gradual decrease with time $(t)$ of degradation, while that of the new peak ( $1^{\text {st }}$ peak $)$ increased in the same direction. This behavior indicated that gatifloxacin undergoes significant degradation under forced acidic conditions. A suggested degradation reaction is shown in Scheme 2 which is based on the hydrolysis of gatifloxacin through the cleavage of the $\mathrm{C}_{7}-\mathrm{N}_{1}$ bond ${ }^{51}$ and decarboxylation at $\mathrm{C}_{3}-\mathrm{COOH}$ bond ${ }^{52}$ that resulted in two products of degradation (II and III).

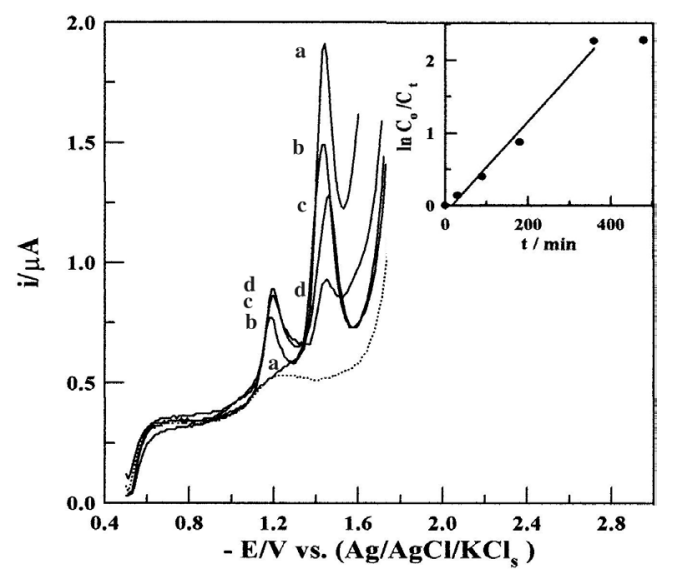

Figure 6. SW-AdCS voltammograms of $5.0 \times 10^{-7} \mathrm{~mol} \mathrm{~L}^{-1}$ gatifloxacin during induced degradation in $2.5 \mathrm{~mol} \mathrm{~L}^{-1} \mathrm{HCl}$ for different time intervals $\mathrm{t}$ : (a) 0, (b) 90, (c) 180, and (d) $360 \mathrm{~min} ; \mathrm{pH} \mathrm{7,} \mathrm{t}_{\text {acc }}=30$ (Dotted line is the background). Insert: $\ln \left(\mathrm{C}_{\mathrm{o}} / \mathrm{C}_{\mathrm{t}}\right)$ versus time $\mathrm{t}$ plot.

The suggested sites of degradation were confirmed by the AM1 semi-empirical molecular orbital calculations of the bond orders throughout gatifloxacin molecule. The calculations revealed that the weakest bond orders within the gatifloxacin molecule are $\mathrm{C}_{7}-\mathrm{N}_{1}(0.9941)$ and $\mathrm{C}_{3}-\mathrm{COOH}$ (0.9777). The suggested product 2-methyl- 




(I)



(II)<smiles>CC1C[NH2+]CCN1</smiles>

(III)

Scheme 2

piperazine (II) is electro-inactive at the mercury electrode, while product (III), 6-fluoro-7-hydroxy-8methoxy-1-cyclopropyl-4-oxo-quinoline, is electroactive. The reduction along the $1^{\text {st }}$ peak $\left(\mathrm{E}_{\mathrm{p}}=-1.20 \mathrm{~V}\right)$ and $2^{\text {nd }}$ peak $\left(E_{p}=-1.45 \mathrm{~V}\right)$ corresponds to reduction of the $\mathrm{C}=\mathrm{O}$ double bond of the degraded product (III) and that of gatifloxacin (I), respectively. The $\mathrm{C}=\mathrm{O}$ double bond of the degraded product (III) is more susceptible to reduction $\left(\mathrm{E}_{\mathrm{p}}=-1.20 \mathrm{~V}\right)$ than that of gatifloxacin $(\mathrm{I})\left(\mathrm{E}_{\mathrm{p}}=\right.$ $-1.45 \mathrm{~V}$ ) which may be due to the steric hindrance on the latter. On the other side, voltammograms of gatifloxacin solution treated with $2.5 \mathrm{~mol} \mathrm{~L}^{-1} \mathrm{NaOH}$ showed no additional reduction peak indicating enough stability of gatifloxacin in alkaline medium. Mean percentage recoveries $(\% \mathrm{R})$ of gatifloxacin in its treated solutions with $\mathrm{HCl}$ were estimated by means of the described SW-AdCS voltammetric (Table 3).

\section{Degradation kinetics}

Concentrations of the unchanged gatifloxacin and consequently the percentage recoveries at different time intervals $(\mathrm{t})$ of treatment with $\mathrm{HCl}$ were estimated by means of the described stripping voltammetric method using the calibration plot method (Table 3). The achieved recovery of gatifloxacin within the level of about $10 \%$ suggested a significant degradation of gatifloxacin during the forced treatment in the acid solution. Variation of concentration $\left(\mathrm{C}_{\mathrm{t}}\right)$ of gatifloxacin with time $(\mathrm{t})$ of degradation is exponential indicating first-order kinetics. A linear-fit relationship between $\ln \left(\mathrm{C}_{\mathrm{o}} / \mathrm{C}_{\mathrm{t}}\right)$ and time $t$ was obtained up to $360 \mathrm{~min}$ (Figure 6, Insert), which means that degradation process of gatifloxacin follows pseudo first-order kinetics. From slope value of $\ln \left(\mathrm{C}_{\mathrm{o}} / \mathrm{C}_{\mathrm{t}}\right)$ versus time t plot, the apparent degradation rate constant $(\mathrm{k})$ and half-life $\left(\mathrm{t}_{1 / 2}\right)$ were estimated and found to be $6.3 \times 10^{-3} \mathrm{~min}^{-1}$ and $115.5 \mathrm{~min}$, respectively.

\section{Applications}

Assay of gatifloxacin in presence of its degradation products

Stability indicating property of the described SW-AdCS voltammetric method was studied. Figure 7 illustrates SW-AdCS voltammograms of $5.0 \times 10^{-7} \mathrm{~mol} \mathrm{~L}^{-1}$ gatifloxacin solution after forced acid degradation for 480 min (curve a) and that of the same degraded solution to which $5.0 \times 10^{-8} \mathrm{~mol} \mathrm{~L}^{-1}$ standard gatifloxacin solution was added (curve b). As shown in Figure 7, the cathodic peak of standard gatifloxacin and that of its degradation product are well-resolved. Moreover, the percentage recovery of the added standard gatifloxacin was found to be $102.18 \pm 0.98$ indicating the successful assay of gatifloxacin without interference from its acid-induced degradation products Therefore, the method could be used successfully as a stability-indicating method for assay of gatifloxacin.

\section{Assay of tequin ${ }^{\circledast}$ tablets}

The described SW-AdCS voltammetric method was successfully applied to assay of gatifloxacin in tequin ${ }^{\circledR}$ tablets solution, using the calibration plot method, without the necessity for samples pretreatment and /or time-consuming extraction steps prior to analysis (Table 4). The validity of the described method was further assessed by applying the standard addition method ${ }^{53}$ for three different standard gatifloxacin solutions added to pre-analyzed tablet solutions. The analysis exhibited also satisfactory results, which were statistically compared with those, obtained by a reported

Table 3. Main percentage recovery (\% R) of $5.0 \times 10^{-7} \mathrm{~mol} \mathrm{~L}^{-1}$ gatifloxacin solution, at different time (t) intervals of forced degradation by refluxing with $2.5 \mathrm{~mol} \mathrm{~L}^{-1} \mathrm{HCl}$ solution, using the described SW-AdCS voltammetric method; B-R universal buffer of $\mathrm{pH} \mathrm{7;} \mathrm{t}_{\text {acc }}=30 \mathrm{~s}(\mathrm{n}=3)$

\begin{tabular}{lccccc}
\hline Reflux time t / min & 0 & 30 & 90 & 180 & 480 \\
$\mathrm{C}_{\text {Found }} /\left(\mathrm{mol} \mathrm{L}^{-1}\right)$ & $5.08 \times 10^{-7}$ & $4.40 \times 10^{-7}$ & $3.23 \times 10^{-7}$ & $2.22 \times 10^{-7}$ & $0.53 \times 10^{-7}$ \\
$\% \mathrm{R}$ & 101.6 & 88.0 & 64.6 & 44.4 & 10.6 \\
\hline
\end{tabular}






Figure 7. SW-AdCS voltammograms of $5.0 \times 10^{-7} \mathrm{~mol} \mathrm{~L}^{-1}$ gatifloxacin recorded following induced degradation in $2.5 \mathrm{~mol} \mathrm{~L}^{-1} \mathrm{HCl}$ for $480 \mathrm{~min}$ (curve a) and for the same solution in presence of $5.0 \times 10^{-8} \mathrm{~mol} \mathrm{~L}^{-1}$ standard gatifloxacin solution (curve b); $\mathrm{pH}=7$ and $\mathrm{t}_{\mathrm{acc}}=30 \mathrm{~s}$.

spectrophotometric method. ${ }^{28}$ Since the calculated $F$-value did not exceed the theoretical one (Table 4), there was no significant difference between the described and reported methods with respect to reproducibility ${ }^{54}$ Also, no significant difference was noticed between the two methods regarding accuracy and precision as revealed by $t$-test value, ${ }^{54}$ Table 4 .

Table 4. Assay of Tequin ${ }^{\circledR}$ tablets (400 mg / tablet) by the described SW-AdCS voltammetric method $\left(\mathrm{t}_{\text {acc }}=100 \mathrm{~s}\right.$, ) and a reported UV-spectrophotometric method ${ }^{28}$

Recovery (\%R \pm R.S.D) by the described method

(Calibration curve method)

Recovery (\%R \pm R.S.D) by the described method (Standard addition method)

Recovery ( $\% \mathrm{R} \pm$ R.S.D) by the reported method $^{28}$ (Standard addition method)

$F$-value

$t$-test

Theoretical $F$-value $=6.39$ and $t$-value $=2.3$ at $95 \%$ confidence limit for $\mathrm{n}_{1}=5$ and $\mathrm{n}_{2}=5$.

\section{Assay of spiked serum samples}

A quantitative assay of gatifloxacin spiked in human serum was carried out by the described SW-AdCS voltammetric method without the necessity for samples pretreatment and /or time-consuming extraction steps prior to the analysis. Representative SW-AdCS voltammograms of various concentrations of gatifloxacin spiked in human serum are shown in Figure 8. As can be seen in Figure 8 (curve a); no interfering peaks were observed in the blank human serum within the studied potential range. LOD of $2.2 \times 10^{-9} \mathrm{~mol} \mathrm{~L}^{-1}$ and LOQ of $7.3 \times 10^{-9} \mathrm{~mol} \mathrm{~L}^{-1}$ gatifloxacin in the spiked serum samples were achieved by the described method. Mean percentage recovery of $101.06 \pm 1.21$ was achieved by four replicate measurements.

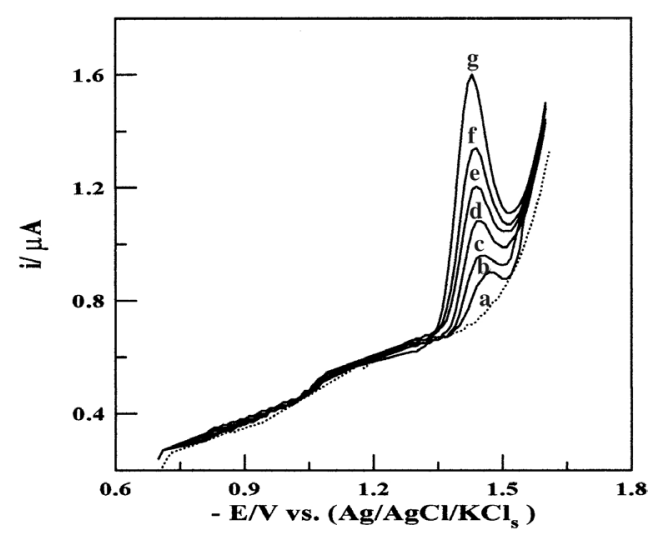

Figure 8. SW-AdCS voltammograms for various concentrations of gatifloxacin spiked in human serum in a B-R universal buffer of $\mathrm{pH} 7$ : (a) Background, (b) $1.0 \times 10^{-8}$, (c) $3.0 \times 10^{-8}$, (d) $5.0 \times 10^{-8}$, (e) $7.0 \times 10^{-8}$, (f) $1.0 \times 10^{-7}$, and (g) $2.0 \times 10^{-7} \mathrm{~mol} \mathrm{~L}^{-1} ; \mathrm{E}_{\text {acc. }}=-0.7 \mathrm{~V}, \mathrm{t}_{\text {acc. }}=100 \mathrm{~s}$, $\mathrm{f}=80 \mathrm{~Hz}, \Delta \mathrm{E}_{\mathrm{s}}=10 \mathrm{mV}$ and $\mathrm{a}=25 \mathrm{mV}$.

\section{Effect of potential interferences}

Interferences from some foreign species such as $\mathrm{Ca}^{2+}$, $\mathrm{Mg}^{2+}, \mathrm{Zn}^{2+}, \mathrm{Al}^{3+}, \mathrm{Cd}^{2+}, \mathrm{Fe}^{3+}, \mathrm{Cu}^{2+}, \mathrm{Na}^{+}, \mathrm{K}^{+}$, glucose, valine, phenylalanine and ethylenediamine (as a metabolite of gatifloxacin) on analysis of $2.0 \times 10^{-7} \mathrm{~mol} \mathrm{~L}^{-1}$ gatifloxacin spiked in human serum were identified by means of the described SW-AdCS voltammetric method (Table 5). Moreover, the interferences from some typical coadministered drugs such as vitamins ( $\mathrm{C}$ and $\mathrm{E}$ ), paracetamol, aspirin, ibuprofen, terfenadine, repaglinide and rabeprazole were also studied (Table 5). Results of the Tolerance levels of each of the investigated species reported in Table 5 indicated that none of these substances was found to interfere with analysis of gatifloxacin. This may be due to that some of the foreign species are electro-inactive or they did not generate any voltammetric signal within the applied range of potential under the operational experimental conditions. Besides, the cathodic peaks of the electroactive species appeared at much less negative potentials (e.g. $\mathrm{Zn}^{2+}: \mathrm{E}_{\mathrm{p}}=-0.85 \mathrm{~V}$, and rabeprazole: $\mathrm{E}_{\mathrm{p}}=-1.03 \mathrm{~V} v s . \mathrm{Ag} / \mathrm{AgCl} / \mathrm{KCl}_{\mathrm{s}}$ ) than that of gatifloxacin $\left(\mathrm{E}_{\mathrm{p}}=-1.45 \mathrm{~V}\right)$. Therefore, the described SWAdCS voltammetric method can be successfully applied to assay of gatifloxacin in biological fluids without interferences from foreign organic and inorganic species.

\section{Pharmacokinetic studies}

A pharmacokinetic study was performed on the plasma samples of two healthy volunteers (about 40-years old) 
Table 5. Interferences from foreign species on analysis of $2 \times 10^{-7} \mathrm{~mol} \mathrm{~L}^{-1}$ gatfloxacin by the described SW-AdCS voltammetric method

\begin{tabular}{lc}
\hline Foreign species & $\begin{array}{c}\text { Tolerance level*/ } \\
\left(\mathrm{mol} \mathrm{L}^{-1}\right)\end{array}$ \\
\hline $\mathrm{Ca}^{2+}, \mathrm{Mg}^{2+}, \mathrm{Cd}^{2+}, \mathrm{Cu}^{2+}$ & $1 \times 10^{-4}$ \\
$\mathrm{Zn}^{2+}, \mathrm{Fe}^{3+}, \mathrm{Al}^{3+}$ & $5 \times 10^{-5}$ \\
$\mathrm{Na}^{+}$and $\mathrm{K}^{+}$ & $5 \times 10^{-4}$ \\
$\mathrm{Glucose}^{+}$ & $2 \times 10^{-4}$ \\
Valine, Phenylalanine & $1 \times 10^{-5}$ \\
Ethylenediamine & $4 \times 10^{-5}$ \\
Vitamins (C and E), & $8 \times 10^{-5}$ \\
Paracetamol, Aspirin, Ibuprofen, \\
Terfenadine and Repaglinide \\
Rabeprazole
\end{tabular}

*For 5\% signal error.

by the described stripping voltammetry method following an oral administration of a single dose of tequin ${ }^{\circledR}$ tablet (400 mg gatifloxacin). No interfering voltammetric peak was observed with that of gatifloxacin during the assay of the plasma samples. The obtained plasma concentrationtime profiles of the two subjects are shown in Figure 9. The pharmacokinetic parameters: the area under the plasma concentration-time profile from time zero to the last measurable sample time $\left(\mathrm{AUC}_{0 \text { to } 24}\right)$ and to infinity $\left(\mathrm{AUC}_{0 \text { too }}\right)$; the maximum plasma concentration $\left(\mathrm{C}_{\max }\right)$; time of the maximum plasma concentration $\left(\mathrm{t}_{\max }\right)$; terminal rate constant $\left(\mathrm{K}_{\mathrm{el}}\right)$ and terminal half-life time $\left(\mathrm{t}_{1 / 2}\right)$ were estimated. $\mathrm{C}_{\max }$ and $\mathrm{t}_{\max }$ were estimated directly from the concentrationtime profile. The area under the plasma concentration-time profile from time zero (pre-dose) to time of last quantifiable

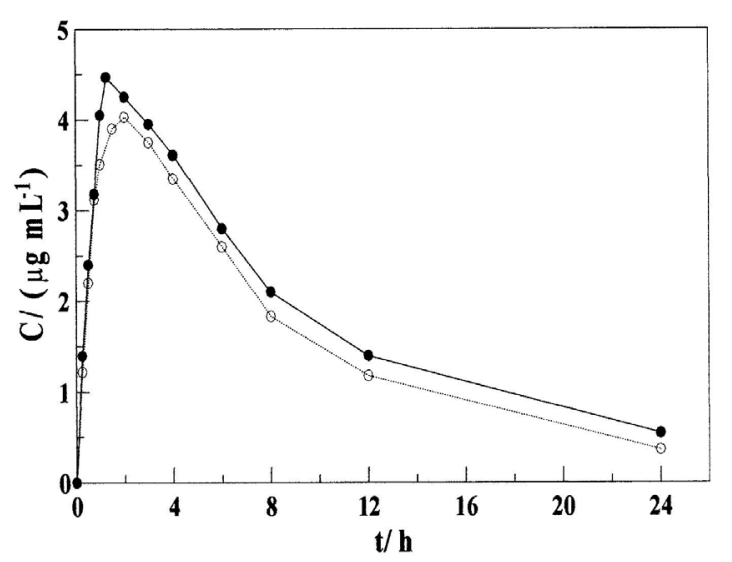

Figure 9. Mean plasma concentration- time profiles for two subjects following an oral administration of a single dose of Tequin ${ }^{\circledast}$ tablet $(400 \mathrm{mg}$ gatifloxacin).
Table 6. Estimated plasma pharmacokinetic parameters of two subjects following an oral administration of a single dose (Tequin ${ }^{\circledR}$ tablet, $400 \mathrm{mg}$ gatifloxacin)

\begin{tabular}{lcc}
\hline \multirow{2}{*}{ Parameter / Unit } & \multicolumn{2}{c}{ Estimated values* } \\
& Subject (1) & Subject (2) \\
\hline $\mathrm{C}_{\max } /\left(\mu \mathrm{g} \mathrm{mL}^{-1}\right)$ & 4.47 & 4.03 \\
$\mathrm{t}_{\max } / \mathrm{h}$ & 1.50 & 2.00 \\
$\mathrm{AUC}_{0 \text { to } 24} /\left(\mu \mathrm{g} \mathrm{h} \mathrm{mL}^{-1}\right)$ & 42.91 & 37.69 \\
$\mathrm{AUC}_{0 \text { t o } \infty} /\left(\mu \mathrm{g} \mathrm{h} \mathrm{mL}^{-1}\right)$ & 50.28 & 42.52 \\
$\mathrm{~K}_{\mathrm{el}} / \mathrm{h}^{-1}$ & 0.075 & 0.079 \\
$\mathrm{t}_{1 / 2} / \mathrm{h}$ & 9.28 & 8.75 \\
\hline
\end{tabular}

*Average of two measurements.

concentration $\left(\mathrm{AUC}_{0}\right.$ to 24 ) was estimated using the linear trapezoidal method. The terminal rate constant $\left(\mathrm{K}_{\mathrm{el}}\right)$ was estimated by applying a log - linear regression analysis to at least the last three time points. The terminal half-life time $\left(\mathrm{t}_{1 / 2}\right)$ was estimated as $\left[\ln 2 / \mathrm{K}_{\mathrm{e}]}\right]$. The area under the plasma concentration-time profile from time zero to infinity $\left(\mathrm{AUC}_{0 \text { to } \infty}\right)$ was estimated as $\left[\mathrm{AUC}_{0 \text { to } 24}+\left(\mathrm{C}_{24} / \mathrm{K}_{\mathrm{el}}\right)\right.$ ], Table 6 . The obtained plasma concentration-time profiles and the estimated pharmacokinetic parameters were favorably compared with those reported in literature ${ }^{2-4}$ confirming the reliability of the described SW-AdCS voltammetric method for assay of gatifloxacin in human plasma.

\section{Conclusions}

A validated, simple, sensitive, precise and selective stability-indicating square-wave adsorptive cathodic stripping voltammetric method was described for the trace quantification of gatifloxacin in bulk form, pharmaceutical formulation, and human blood without interferences from excipients present in tablets, endogenous substances present in human blood or its degradation products. The method could be recommended for analysis of the drug in quality control analysis and clinical laboratories.

\section{Acknowledgments}

The author express her gratitude to Ramadan Specialized Hospital's staff, (Tanta City, Egypt), for the kind care of the two volunteers and for providing the great facilities for collecting and treatments of the plasma samples required for the pharmacokinetic studies.

\section{References}

1. Blondeau, J. M.; Laskowski, R.; Bjarnason, J.; Stewart, C.; Int. J. Antimicrob. Agents 2000, 14, 45. 
2. Clinical pharmacology, www.rxlist.com/cgi/generic3/gatifloxacin. htm, accessed in January 13, 2005.

3. Nakashima, M.; Uematsu, T.; Kosuge, K.; Kusajima, H.; Ooie, T.; Masuda, Y.; Ishida, R.; Uchida, H.; Antimicrob. Agents Chemother. $\mathbf{1 9 9 5}, 39,2635$.

4. Hosaka, M.; Yasue, T.; Fukuda, H.; Tomizawa, H.; Aoyama, H.; Hirai, K.; Antimicrob. Agents Chemother. 1992, 36, 2108.

5. Mirza, S.; Rabindra, N.; Hassan D. M.; Huda, N.; Shaikh, F.; Chin. J. Chromatogr. 2008, 26, 358.

6. Salazar-Cavazos, M. L.; Gonzalez, L. Y. C.; De Lerma, G. G.; De Torres, N. W.; Chromatographia 2006, 63, 605.

7. Salgado, W. R. N.; Lopes, C. C. G. O.; J. AOAC Int. 2006, 89, 642.

8. Al-Dgither, S.; Alvi, S. N.; Hammami, M. A.; J. Pharm. Biomed. Anal. 2006, 41, 251.

9. Santoro, M. I. R. M.; Kassab, N. M.; Singh,A. K.; Kedor-Hackmam, E. R. M.; J. Pharm. Biomed Anal. 2006, 40, 179.

10. Shirke, T. R.; Pai, N.; Asian J. Chem. 2004, 16, 546.

11. Overholser, B. R.; Kays, M. B.; Sowinski, K. M.; J. Chromatogr., B 2003, 798, 167 .

12. Liang, H. R.; Kays, M. B.; Sowinski, K. M.; J. Chromatogr, B 2002, 772,53

13. Borner, K.; Hartwig, H.; Lode, H.; Chromatographia 2000, 52, S105.

14. Sowmiya, G.; Gandhimathi, M.; Ravi, T. K.; Sireesaa, K. R.; Indian J. Pharm. Sci. 2007, 69, 301.

15. Suhagia, B. N.; Shah, S. A.; Rathod, I. S.; Patel, H. M.; Shah, D. R.; Marolia, B. P.; Anal. Sci. 2006, 22, 743.

16. Motwani, S. K.; Khar, R. K.; Ahmed, F. J.; Chopra, S.; Kohli, K.; Talegaonkar, S.; Iqbal, Z.; Anal. Chim. Acta 2006, 576, 253.

17. Vishwanathan, K.; Bartlett, M. G.; Stewart, J. T.; Rapid Commun. Mass Spectrom. 2001, 15, 915.

18. Nguyen, H. A.; Grellet, J.; Ba, B. B.; Quentin, C.; Saux, M. C.; J. Chromatogr., B 2004, 810, 77.

19. Zhu, X. S.; Gong, A. Q.; Yu, S. H.; Spectrochim. Acta, Part A 2008, 69, 478.

20. Razek, T. M. A.; El-Baqary, R. I.; Ramadan, A. E.; Anal. Lett. 2008, 41, 417.

21. Colunga-Gonzalez, L. Y.; De Lerma, M. G. G.; De Torres, N. W.; Salazar-Cavazos, M. D. L.; Anal. Lett. 2005, 38, 2355.

22. Ocana, J. A.; Barragan, F. J.; Callejon, M.; J. Pharm. Biomed. Anal. $\mathbf{2 0 0 5}, 37,327$.

23. Guo, C. C.; Dong, P.; Chu, Z. J.; Wang, L.; Jiang, W.; Luminescence 2008, 23,7 .

24. Gouda, A. A. F.; El-Sheikh, R.; Amin, A. S.; Chem. Pharm. Bull. 2008, 56,34 .

25. Gao-wa, A.; Yu-long, T.; Hai-yan, F.; Spectrosc. Spect. Anal. 2007, 27, 1615.

26. Amin, A. S.; Gouda,A. A. F.; El-Shiekh, R.; Zahran F.; Spectrochim. Acta, Part A 2007, 67, 1306.

27. Salgado, H. R. N.; Oliveira, C. L. C. G.; Pharmazie 2005, 60, 263.

28. Venugopal, K.; Saha, R. N.; Il Farmaco 2005, 60, 906.
29. Faria, A. F.; De Souza, M.V. N.; De Oliveira, M. A. L.; J. Braz Chem. Soc. 2008, 19, 389.

30. Sun, H. W.; He, P.; Lv, Y. k; Liang S. X.; J. Chromatogr, B 2007, $852,145$.

31. Faria, A. F.; De Souza, M. V. N.; De Almeida, M. V.; De Oliveira, M. A. L.; Anal. Chim. Acta 2006, 579, 185.

32. Sane, R. T.; Menon, S.; Pathak, A. R.; Deshpande, A. Y.; Mahale, M.; Chromatographia 2005, 61, 303.

33. Xie, X.; Shao, X.; Yue, Q.; Huang, C.; Song Z.; Anal. Lett. 2007, 40, 1951.

34. Lian, N.; Zhao, H. C.; Sun, C. Y.; Jin, L. P.; Zhang, Z. L.; Zheng, Y. Z.; Chem. J. Chin. Univ.-Chin. 2002, 23, 564.

35. Reddy, T. M.; Balaji, K.; Reddy, S. J.; J. Anal. Chem. 2007, 62, 168

36. Abdel Ghani, N. T.; El Ries, M.A.; El-Shall, M.A.; Anal. Sci. 2007, 23, 1053.

37. Guo, M.; Yu, Q. S.; Anal. Sci. 2006, 22, 685.

38. El Ries, M. A.; Wassel, A. A.; Abdel Ghani, N. T.; El-Shall, M. A.; Anal. Sci. 2005, 21, 1249.

39. Han-Ying, Z.; Mei-Zhen, N.; Zhi-Qi, Z.; Li-Ping, K.; At. Spectrosc. 2008, 29, 32.

40. Al-Ghannam, S. M.; Spectrochim. Acta, Part A 2008, 69, 1188.

41. Ragab, G. H.; Amin, A. S.; Spectrochim. Acta, PartA 2004, 60, 973.

42. Zuman, P.; The Elucidation of Organic Electrode Process, Academic Press: New York, 1969.

43. Bond, A. M.; Modern Polarographic Methods in Analytical Chemistry, Dekker Marcel: New York, 1980.

44. Laviron, E.; J. Electroanal. Chem. 1974, 52, 355.

45. Bard,A. J.; Faulkner,L. R.; Electrochemical Methods: Fundamentals and Applications, John Wiley \& Sons: New York, 1980.

46. Monk, P.; Fundamentals of Electroanalytical Chemistry, Wiley: New York, 2001.

47. Laviron, E.; Roullier, L.; Degrand, C.; J. Electroanal. Chem. 1980, $112,11$.

48. Miller, J. C.; Miller, J. N.; Statistics for Analytical Chemistry, $4^{\text {th }}$ ed., Ellis-Howood: New York, 1984.

49. The USA Pharmacopoeia; The National Formulary, USP 26, Convention Inc. 2003.

50. ICH, Proceedings of the International Conference on Harmonization, ICH Q1A, Stability Testing of New Drug Substances and Products, Geneva, 1993.

51. Ojha, T.; Bakshi, M.; Chakraborti, A. K.; Singh, S.; J. Pharm. Biomed. Anal. 2003, 31, 775.

52. El-Gindy, A.; J. Pharm. Biomed. Anal. 2000, 22, 215.

53. Ewing, G. W.; Instrumental Methods of Chemical Analysis, $5^{\text {th }}$ ed., Lippincott-Raven: Philadelphia, 1995.

54. Christian, G. D.; Analytical Chemistry, $5^{\text {th }}$ ed., John Wiley Sons Inc.: USA, 1994.

Received: November 19, 2008 Web Release Date: October 9, 2009 